\title{
Transmission of Aggregatibacter actinomycetemcomitans between Brazilian Women with Severe Chronic Periodontitis and their Children
}

\author{
Rodrigo Otávio Citó César RÊGO ${ }^{1}$ \\ Denise Madalena Palomari SPOLIDORIO ${ }^{2}$ \\ Sérgio Luiz de Souza SALVADOR ${ }^{3}$ \\ Joni Augusto CIRELLI ${ }^{4}$
}

\begin{abstract}
${ }^{1}$ Department of Clinical Dentistry, School of Pharmacy, Dentistry and Nursing, Federal University of Ceará, Fortaleza, CE, Brazil ${ }^{2}$ Department of Physiology and Pathology, School of Dentistry of Araraquara, São Paulo State University, Araraquara, SP, Brazil ${ }^{3}$ Department of Clinical, Toxicologic and Bromatologic Analysis, School of Pharmaceutical Sciences of Ribeirão Preto, University of São Paulo, Ribeirão Preto, SP, Brazil

${ }^{4}$ Department of Diagnosis and Surgery, School of Dentistry of Araraquara, São Paulo State University, Araraquara, SP, Brazil
\end{abstract}

\begin{abstract}
This study evaluated the transmission of Aggregatibacter actinomycetemcomitans (Aa) in women with severe chronic periodontitis and their children. Thirty women (mean age $=36.1 \pm 6.0$ years) who were mothers of at least one child aged 7 to 16 years were enrolled. In order to investigate mother-child transmission of $A a$, the children were also evaluated when their mothers were colonized by the bacterium. Subgingival plaque samples of each woman were collected from 3 sites (mean probing depth of $7.3 \pm 1.2 \mathrm{~mm}$ and mean clinical attachment level of $7.9 \pm 1.5 \mathrm{~mm}$ ) and pooled in reduced transport fluid (RTF). These samples were processed, inoculated onto TSBVagar selective medium and incubated at $37^{\circ} \mathrm{C}$ in microaerophilic atmosphere for 5 days. Aa was identified on the basis of colony morphology, Gram staining, catalase and oxidase reactions. Aa was found in 8 out of 30 women. Therefore, 8 children from these women (mean age $=12 \pm 3.7$ years) were evaluated, but $A a$ was found only in 2 of them. A $a$ strains of the two mother-child pairs were evaluated by arbitrarily-primed polymerase chain reaction (AP-PCR), although it was not found similarity between the amplitypes of each pair. No Aa transmission was found between Brazilian women with severe chronic periodontitis and their children.
\end{abstract}

Key Words: periodontal diseases, microbiology, Aggregatibacter actinomycetemcomitans, periodontal diseases, transmission, families.

\section{INTRODUCTION}

The initial event in periodontal diseases is the transmission of periodontopathogens, usually from the oral cavity of a family member to another. Tissue destruction factors produced by these pathogens can cause loss of connective tissue attachment and alveolar bone by evading host defense mechanisms (1).

Aggregatibacter actinomycetemcomitans (Aa) is a recognized virulent periodontopathogen that has been associated with the etiology and pathogenesis of periodontal diseases $(2,3)$. Aa transmission between family members with different profiles of periodontal diseases and in different geographic areas of the world has been demonstrated (4-8). Tinoco et al. (4) evaluated $A a$ transmission in Brazilian families of aggressive periodontitis patients. However, as far as it could be ascertained, there seems to be no available studies about Aa transmission between Brazilian families of chronic periodontitis patients.

Studies on the occurrence of periodontopathogens and prevalence of periodontal diseases in different populations are relevant due to geographic location, socioeconomic conditions and genetic heterogeneity. 
These characteristics have a relationship with both the prevalence of periodontal diseases and the pathogens related to them (9-15). Furthermore, studies about the transmission of periodontopathogens are valuable to elucidate its significance as a risk factor for the establishment of periodontal diseases and to search available ways for their prevention (16).

This study evaluated $A a$ transmission between Brazilian women with chronic periodontitis and their children.

\section{MATERIAL AND METHODS}

\section{Subjects}

This study comprised 30 women with severe chronic periodontitis, who had been referred to the Periodontics Service of the School of Dentistry of Araraquara, UNESP, Brazil, for periodontal treatment. The selected patients had at least 3 sites with $6 \mathrm{~mm}$ of probing depth and clinical attachment loss and had at least one child aged 7 to 16 years. In order to evaluate mother-child transmission, the children were included in the study when their mothers were colonized by Aa.

The following conditions were considered as exclusion criteria for both mothers and children: periodontal treatment within the previous 6 months or antibiotic therapy within the previous 3 months; systemic alterations that could have interfered with the periodontal conditions or acute periodontal diseases; use of any medication associated with gingival overgrowth; be pregnant or in lactation periods.

The study protocol was approved by the Ethics in Human Research Committee of the School of Dentistry of Araraquara, UNESP, Brazil. All subjects were given full information about the study design and procedures and all signed a written informed consent form.

\section{Clinical Examination}

All patients were examined by the same calibrated observer. Measurements were made on all totally erupted teeth, except for third molars. The following measurements were recorded: presence of visible plaque and gingival bleeding, dichotomously obtained from the plaque and gingival indexes (17); probing depth (PD); clinical attachment loss (CAL); and bleeding on probing (BOP). PD, CAL and BOP were evaluated at 6 sites, at the mesiobuccal, buccal, distobuccal, distolingual, lingual and mesiolingual positions. Clinical examination was performed with a PCP-UNC 15 periodontal probe (HuFriedy Mfg. Co. Inc., Chicago, IL, USA).

\section{Microbiological Procedure}

The women were screened by bacterial culture for the presence of subgingival Aa. Samples of the children were collected when their mothers were colonized by the periodontopathogen. When present both in the mother and in her child, Aa colonies of each one were randomly chosen, evaluated by arbitrarily-primed polymerase chain reaction (AP-PCR) and compared in order to investigate bacterial transmission.

\section{Bacterial Sampling and Culture}

In the mothers, subgingival bacterial samples were collected with a periodontal curette from 3 sites that presented the worst periodontal destruction, with at least $6 \mathrm{~mm}$ of PD and CAL, and BOP. In the children, the samples were also collected with a periodontal curette from 3 sites that presented the worst periodontal destruction, but in the absence of this factor, samples were collected mesially from 3 permanent first molars.

Prior to sampling, supragingival plaque and calculus at the sample sites were removed and the respective areas were isolated with sterile cotton rolls. Each patient's samples were pooled and immediately immersed in reduction transport fluid (RTF) (18). All samples were processed within 2 to $6 \mathrm{~h}$ after sampling, being dispersed by vortexing and $10^{-1}$ to $10^{-3}$ dilutions were then prepared with RTF from each sample. These dilutions were plated onto tryptic soy-serum-bacitracin-vancomycin (TSBV) agar (19) and incubated in $10 \% \mathrm{CO}_{2}$ in air at $37^{\circ} \mathrm{C}$ for 5 days. Aa was identified based on colony morphology, presence of a star-like inner structure, Gram staining, positive catalase test and negative oxidase test.

\section{DNA Extraction}

Aa isolates were cultured in $6 \mathrm{~mL}$ brain heart infusion broth, supplemented with yeast extract $(0.6 \%)$ and L-cystine $(0.02 \%)$, for $24 \mathrm{~h}$ in an atmosphere of $10 \% \mathrm{CO}_{2}$ in air at $37^{\circ} \mathrm{C}$. Bacterial cells were harvested by centrifugation ( $10.000 \mathrm{xg}$ for $10 \mathrm{~min}$ ), washed twice on TE buffer (10 mM Tris, pH 7.6, 1 mM EDTA) and 
resuspended in $567 \mu \mathrm{L}$ of TE, $30 \mu \mathrm{L}$ of $10 \%$ SDS and $3 \mu \mathrm{L}$ of $20 \mathrm{mg} / \mathrm{mL}$ proteinase $\mathrm{K}$. This solution was incubated at $37^{\circ} \mathrm{C}$ for $60 \mathrm{~min}$ to induce cell lysis. Next, $150 \mu \mathrm{L}$ of $5 \mathrm{M} \mathrm{NaCl}$ and $80 \mu \mathrm{L}$ of CTAB$/ \mathrm{NaCl}$ solution (10\% hexadecyltrimethylammonium bromide / $0.7 \mathrm{M}$ $\mathrm{NaCl}$ ) were added and incubated at $65^{\circ} \mathrm{C}$ for $20 \mathrm{~min}$.

Samples were extracted twice with equal volumes of chloroform-isoamyl alcohol (24:1) and twice with phenol-chloroform-isoamyl alcohol (25:24:1). DNA was precipitated by adding $600 \mu \mathrm{L}$ of isopropanol and centrifuged (12.000 x g for $30 \mathrm{~min}$ ). DNA precipitate was rinsed once with $600 \mu \mathrm{L}$ of cold $70 \%$ ethanol. After centrifugation (12.000 x g for $15 \mathrm{~min}$ ), ethanol was removed and DNA resuspended in $200 \mu \mathrm{L}$ of TE buffer.

\section{Arbitrarily Primed Polymerase Chain Reaction (AP-PCR)}

The $25 \mu \mathrm{L}$ reaction mixtures contained $10 \mathrm{mM}$ PCR buffer (Invitrogen/Life Technologies do Brasil, São Paulo, SP, Brazil), $50 \mathrm{mM} \mathrm{MgCl}{ }_{2}$ (Invitrogen/Life Technologies do Brasil), $0.1 \mathrm{mM} \mathrm{dNTP} \mathrm{mix} \mathrm{(Invitrogen/}$ Life Technologies do Brasil) $0.2 \mu \mathrm{M}$ of primer OPA-03: 5'- AGT CAG CCA C -3' (Operon Technologies, Alameda, CA, USA), 2,5 U DNA Taq polymerase (Invitrogen/Life Technologies do Brasil) and $2 \mathrm{~mL}$ of genomic DNA dissolved on TE buffer.

The thermocycle (GeneAmp PCR System 2400, Perkin Elmer, New Jersey, NY, USA) profile was initiated with a 5 -min denaturation at $94^{\circ} \mathrm{C}$, followed by 45 cycles of $30 \mathrm{~s}$ at $94^{\circ} \mathrm{C}, 30 \mathrm{~s}$ at $42^{\circ} \mathrm{C}$ and $1 \mathrm{~min}$ at $72^{\circ} \mathrm{C}$, with final extension for $3 \mathrm{~min}$ at $72^{\circ} \mathrm{C}$. Amplification products were analyzed eletrophoretically on $1.4 \%$ agarose gels stained with ethidium bromide solution $(0.003 \%)$ and photographed (Kodak Digital Science; Eastman Kodak Company, Rochester, NY, USA) under UV light. Photographs were analyzed with specific

Table 1. Demographic characteristics of subjects.

\begin{tabular}{ccccc}
\hline & $\mathrm{n}$ & $\begin{array}{c}\text { Mean age } \\
(\mathrm{SD})\end{array}$ & Race & $\begin{array}{c}\text { Smoking } \\
\text { status }\end{array}$ \\
\hline Mothers & 30 & $36.1(6.0)$ & $24 \mathrm{w} / 6 \mathrm{~b}$ & $8 \mathrm{~s} / 5 \mathrm{fs} / 17 \mathrm{~ns}$ \\
Children & $4 \mathrm{f} / 4 \mathrm{~m}$ & $12(3.7)$ & $6 \mathrm{w} / 2 \mathrm{~b}$ & - \\
\hline
\end{tabular}

$\mathrm{f}=$ females; $\mathrm{m}=$ males; $\mathrm{SD}=$ standard deviation; $\mathrm{w}=$ whites; $\mathrm{b}=$ blacks; $\mathrm{s}=$ smokers; $\mathrm{fs}=$ formerly smokers; $\mathrm{ns}=$ non-smokers. software (1D Kodak Image Analysis; Eastman Kodak Company) for gel analysis. Aa transmission was based on the similarity of the amplitypes generated from colonies of each mother and her respective child.

\section{RESULTS}

Patients' sex, age, race and smoking status data are shown on Table 1.

For analysis of $A a$ transmission, only children whose mothers had been colonized by the bacterium were evaluated. Aa was found in 8 mothers (27\%), so 1 child per mother was evaluated using the same clinical and microbiologic tests. Aa was found in only 2 children, a 7-year-old white boy and a 13-year-old white girl. Aa colonies of these children and their mothers were evaluated by AP-PCR. The generated amplitypes did not show similarities between the strains of each mother-child pair (Fig. 1).

Table 2 shows the mean values of the periodontal clinical parameters found in the mothers and children.

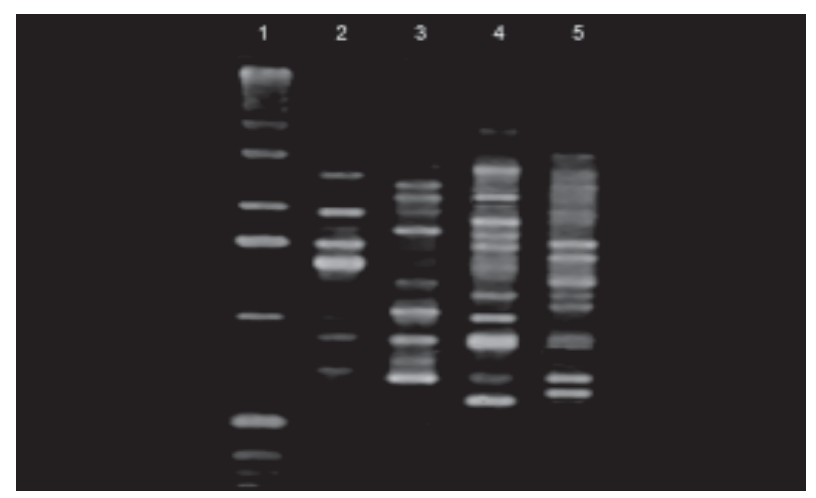

Figure 1. Diagram of Aa DNA-fingerprints of each patient (Lane 1 - molecular weight marker; Lane 2 - mother 1; Lane 3 - mother's 1 daughter; Lane 4 - mother 2; Lane 5 - mother's 2 son) showing no similarities after software analysis.

Table 2. Distribution (\%) of the periodontal clinical parameters among the patients.

\begin{tabular}{lcc}
\hline & Mothers & Children \\
\cline { 2 - 3 } & $49.1(23.2)$ & $30.6(17.6)$ \\
Visible plaque (SD) & $40.4(17.9)$ & $22.1(13.6)$ \\
Gingival bleeding (SD) & $27.2(16.7)$ & - \\
\hline
\end{tabular}

$\mathrm{CAL}=$ clinical attachment loss; $\mathrm{SD}=$ standard deviation. 
According to the American Academy of Periodontology classification of periodontal diseases (20), 9 mothers suffered from severe generalized chronic periodontitis (more than $30 \%$ of sites with CAL $>5 \mathrm{~mm}$ ) and 21 from severe localized chronic periodontitis (less than $30 \%$ of sites with CAL $>5 \mathrm{~mm}$ ) - data not shown. CAL was not found in the periodontal sites of the children. The distribution of PD and CAL means of the sites sampled for microbiologic analysis are show in Table 3.

\section{DISCUSSION}

Several studies have supported the occurrence of Aa transmission between individuals of the same family, but only two of them have evaluated specifically Aa transmission between chronic periodontitis patients and their children: one in The Netherlands (5) and one in the USA (6).

Petit et al. (5) studied the possibility of $A a$ transmission in 13 families among which at least one of the parents were colonized by $A a$. Five out of 26 children had the bacterium and in 4 of these 5, Aa clones were the same as those found in at least one of their parents. Preus et al. (6) evaluated $A a$ vertical transmission in 9 families of individuals with chronic periodontitis, colonized by this bacterium and that had one child was also colonized by the pathogen. Ten children were colonized by $A a$ and 5 showed the same amplitype as their mother or father. These authors selected the study subjects in different ways. Preus et al. (6) evaluated parent-children pairs previously screened for the presence of $A a$. On the other hand, Petit et al. (5), as we did, selected the families on the basis of $A a$ presence in a proband (one of the parents) and then screened the children for its presence. If it were present in the children, transmission would be evaluated. In this study, however, only mothers were enrolled. The bacterium could have been transmitted from the fathers to their children, but this was not investigated.

Previous studies have shown that, usually, each

Table 3. Means of probing depth (PD) (in mm) and clinical attachment loss (CAL) (in $\mathrm{mm}$ ) of the sampled sites.

\begin{tabular}{lcc}
\hline & PD & CAL \\
\hline Mothers & $7.3(1.2)$ & $7.9(1.5)$ \\
Children & $2.3(0.3)$ & - \\
\hline
\end{tabular}

Values in parentheses indicate standard deviation. person is infected by a single $A a$ clone $(7,8)$. In our study, $A a$ colonies to be evaluated by AP-PCR were chosen randomly. The presence of more than one clone per person was not assessed. If the subjects were colonized by more than one clone, the mother-child pairs would share the same clones, but this could not be detected. The subjects could have other clones, but not those that were evaluated. Tinoco et al. (4) evaluated Aa transmission among Brazilian families of aggressive periodontitis patients. Likewise, they found no $A a$ transmission pattern among the subjects, probably due to polyclonal bacterial infection.

Asikainen and Chen (2) hypothesized that in developing countries like Brazil, subjects may be more susceptible to polyclonal colonization by periodontopathogens. They are more likely exposed to a variety of sources than individuals in Europe or in the United States, and might be colonized by a larger number of microorganisms due to the higher incidence of childhood diseases in their countries, which can compromise their immune status (3). Hence, both children colonized by $A a$ in the present study could have acquired it from another person, not their mothers.

Another possibility is due to a technical issue. Molecular biology assays have been used to examine periodontopathogen transmission - restriction endonuclear analysis (5), ribotyping (7) and AP-PCR $(4,6,8)$. This study used AP-PCR, which allows evaluating the similarity between bacterial clonal types and then suggest their transmission. However, primers can target different regions of bacterial genomic DNA in identical clones. Thus, it is possible that transmission had occurred and that the clonal types were identical. Though, it is not possible to show the similarity between them within the different amplitypes generated from different DNA segments $(1,6)$.

It is possible that if the prevalence of $A a$ had been higher, more transmission could have been found. A prevalence of $27 \%$ was observed among the women with severe chronic periodontitis. However, the prevalence of $A a$ is variable worldwide. In Europe, Sanz et al. (14) found a significant difference between the presence of $A a$ in periodontal patients from Spain $(2.3 \%)$ and The Netherlands (23.3\%). Dahlen et al. (11) and Mombelli et al. (15) found prevalences of $88 \%$ and $63 \%$, in Southern Thailand and China, respectively. These authors suggest that $A a$ is a common constituent of the normal microbiota in these populations. Like the present study, all these authors used culture methods to process their samples.

In Brazil, Colombo et al. (12) observed, using checkerboard DNA-DNA hybridization, the presence of 
Aa in $41 \%$ of chronic periodontitis patients' sites and in $25 \%$ of healthy patients' sites. Avila-Campos (13), using culture methods, found a prevalence of $48 \%$ in healthy patients and of $80 \%$ in chronic periodontitis patients. This last study was performed in the same region as the present one. Despite the technique employed, even in the same country or region, the prevalence of the bacterium is variable. Probably, this can be due to the Brazilian population heterogeneity. Different $A a$ prevalence found in Brazil can also be related to the present findings.

In conclusion, within the limitations of this study, Aa transmission between Brazilian women with severe chronic periodontitis and their children was not detected.

\section{ACKNOWLEDGEMENTS}

The authors ackowledge FAPESP (grant \#2000/08658-5) and CAPES (student scholarship) for support; Maraisa Verri for laboratory assistance; andCristianeOliveira, José MarcosFernandes, Maurício Costa, Camila Campos and Marinês Alves for clinical assistance.

\section{RESUMO}

Este estudo avaliou a transmissão de Aggregatibacter actinomycetemcomitans ( $A a)$ entre mulheres com periodontite crônica severa e seus filhos. A amostra constituiu-se de 30 mulheres com idade média de 36,1 $\pm 6,0$ anos, mães de filhos com idade entre 7 e 16 anos. Apenas crianças cujas mães haviam sido colonizadas por Aa foram incluídas. Amostras de placa dentária subgengival foram colhidas de três sítios com profundidade de sonagem média de 7,3 $\pm 1,2$ mm e perda de inserção clínica média de 7,9 $\pm 1,5 \mathrm{~mm}$ e agrupadas em fluido de transporte reduzido (RTF). Estas amostras foram processadas e semeadas em meio seletivo ágar TSBV e incubados a $37^{\circ} \mathrm{C}$ em atmosfera de microaerofilia por 5 dias. Aa foi identificado baseado na morfologia colonial, coloração de Gram e testes da catalase e oxidase. Aa foi detectado em 8 das 30 mulheres . Assim, 8 filhos destas mulheres, com idade média de $12 \pm 3,7$ anos foram investigados, mas $A a$ foi detectado em apenas 2 deles. Cepas de $A a$ dos 2 pares de mães e filhos foram submetidos a análise pela técnica de reação em cadeia de polimerase usando primers arbitrários (AP-PCR), mas os amplitipos de cada par não demonstraram similaridade. Portanto, não foi encontrada transmissão de $A a$ entre mulheres brasileiras com periodontite crônica severa e seus filhos.

\section{REFERENCES}

1. Zambon JJ, Haraszthy VI. The laboratory diagnosis of periodontal infections. Periodontol 2000 1995;7:69-82.

2. Asikainen S, Chen C. Oral ecology and person-to-person transmission of Actinobacillus actinomycetemcomitans and Porphyromonas gingivalis. Periodontol 2000 1999;20:65-81.

3. Fine DH, Kaplan JB, Kachlany SC, Schreiner HC. How we got attached to Actinobacillus actinomycetemcomitans: A model for infectious diseases. Periodontol 2000 2006;42:114-157.
4. Tinoco EM, Sivakumar M, Preus HR. The distribution and transmission of Actinobacillus actinomycetemcomitans in families with localized juvenile periodontitis. J Clin Periodontol 1998;25:99-105.

5. Petit MD, Van Steenbergen TJ, De Graaff J, Van der Velden U. Transmission of Actinobacillus actinomycetemcomitans in families of adult periodontitis patients. J Periodontal Res 1993;28:335-345.

6. Preus HR, Zambon JJ, Dunford RG, Genco RJ. The distribution and transmission of Actinobacillus actinomycetemcomitans in families with established adult periodontitis. J Periodontol 1994;65:2-7.

7. Alaluusua S, Saarela M, Jousimies-Somer H, Asikainen S. Ribotyping shows intrafamilial similarity in Actinobacillus actinomycetemcomitans isolates. Oral Microbiol Immunol 1993;8:225-259.

8. Asikainen S, Chen C, Slots J. Likelihood of transmitting Actinobacillus actinomycetemcomitans and Porphyromonas gingivalis in families with periodontitis. Oral Microbiol Immunol 1996;11:387-394.

9. Haubek D, Ennibi OK, Abdellaoui L, Benzarti N, Poulsen S. Attachment loss in Moroccan early onset periodontitis patients and infection with the JP2-type of Actinobacillus actinomycetemcomitans. J Clin Periodontol 2002;29:657-660.

10. Haffajee AD, Bogren A, Hasturk H, Feres M, Lopez NJ, Socransky SS. Subgingival microbiota of chronic periodontitis subjects from different geographic locations. J Clin Periodontol 2004;31:996-1002.

11. Dahlen G, Widar F, Teanpaisan R, Papapanou PN, Baelum V, Fejerskov O. Actinobacillus actinomycetemcomitans in a rural adult population in southern Thailand. Oral Microbiol Immunol 2002;17:137-142.

12. Colombo AP, Teles RP, Torres MC, Souto R, Rosalem WJ, Mendes MC, et al. Subgingival microbiota of Brazilian subjects with untreated chronic periodontitis. J Periodontol 2002;73:360-369.

13. Avila-Campos MJ, Velasquez-Melendez G. Prevalence of putative periodontopathogens from periodontal patients and healthy subjects in Sao Paulo, SP, Brazil. Rev Inst Med Trop Sao Paulo 2002;44:1-5.

14. Sanz M, van Winkelhoff AJ, Herrera D, Dellemijn-Kippuw N, Simon R, Winkel E. Differences in the composition of the subgingival microbiota of two periodontitis populations of different geographical origin. A comparison between Spain and The Netherlands. Eur J Oral Sci 2000;108:383-392.

15. Mombelli A, Gmur R, Lang NP, Corbert E, Frey J. Actinobacillus actinomycetemcomitans in Chinese adults. Serotype distribution and analysis of the leukotoxin gene promoter locus. J Clin Periodontol 1999;26:505-510.

16. Van Winkelhoff AJ, Boutaga K. Transmission of periodontal bacteria and models of infection. J Clin Periodontol 2005;32 Suppl 6:16-27.

17. Loe H. The Gingival Index, the Plaque Index and the Retention Index Systems. J Periodontol 1967;38:Suppl:610-616.

18. Syed SA, Loesche WJ. Survival of human dental plaque flora in various transport media. Appl Microbiol 1972;24:638-644.

19. Slots J. Selective medium for isolation of Actinobacillus actinomycetemcomitans. J Clin Microbiol 1982;15:606-609.

20. Flemmig TF. Periodontitis. Ann Periodontol 1999;4:32-38.

Accepted October 11, 2007 